\title{
Перспективы коллоидной оптоэлектроники
}

\author{
С.В. Гапоненко \\ Институт физики им. Б. И. Степанова НАН Беларуси, \\ Пр. Независимости 68, Минск 220072, Беларусь \\ эл. nочma: s.gaponenko@ifanbel.bas-net.by
}

DOI 10.34077/RCSP2021-22

B современной оптоэлектронике доминирует эпитаксиальный рост планарных полупроводниковых кристаллов и наноструктур в сочетании с фотолитографией. Этот принцип используется при производстве светодиодов, полупроводниковых лазеров, солнечных элементов и фотодетекторов типа ПЗС-матриц в видео- и фотокамерах. В то же время коллоидные наноструктуры, получаемые без применения эпитаксии и вакуумного осаждения, проявляют квантовые размерные эффекты, позволяющие изменять их оптические свойства, которые можно использовать в различных оптоэлектронных устройствах. Коллоидный синтез нанокристаллов полупроводников («квантовые точrи» и нанопластинки), металлов (наноплазмоника) и диэлектриков, структур «ядро-оболочка», а также плотных ансамблей нанокристаллов позволяет создавать различные устройства, при изготовлении которых вакуумное напыление используется только для создания контактов, а эпитаксиальный рост не используется вовсе. Ниже перечислены основные элементы оптоэлектроники и состояние их реализации на основе коллоидных технологий:

- оптические фильтры (уже применяются);

- лазерные затворы для получения нано- и пикосекундных импульсов в твердотельных лазерах (реализованы для целого ряда лазеров);

- люминофоры, включая биометки, преобразователи спектра для белых светодиодов, спектральные конверторы лазерного излучения (начато применение в телевизорах и компьютерных дисплеях, в дисплеях ай-падов и мобильных телефонов);

- светодиоды (продемонстрирована принципиальная возможность);

- $\quad$ лазеры с оптической накачкой (продемонстрирована принципиальная возможность);

- электрооптические модуляторы (на стадии лабораторных исследований);

- солнечные элементы (на стадии лабораторных исследований).

- фототранзисторы (на стадии лабораторных исследований).

Анализ состояния исследований в этой области позволяет говорить о рождении новой технологической платформы в оптоэлектронике [1], которая сможет в отдельных приложениях замещать традиционные эпитаксиальные технологии.

\section{Лuтература}

[1] S. V. Gaponenko and H. V. Demir, Applied Nanophotonics (Cambridge University Press 2018) - 500 p. 